\title{
Syntactic and Lexico-Semantic Variations in Nigerian English: Implications and Challenges in the ESL Classroom
}

\author{
Uriel Okunrinmeta \\ Department of English Studies, Adekunle Ajasin University, Akungba-Akoko, Nigeria \\ Email: urielok3@yahoo.com
}

Received 19 March 2014; revised 20 May 2014; accepted 30 May 2014

Copyright (C) 2014 by author and Scientific Research Publishing Inc.

This work is licensed under the Creative Commons Attribution International License (CC BY). http://creativecommons.org/licenses/by/4.0/

(c) (i) Open Access

\begin{abstract}
The present study traces the poor performance of Nigerian students in English to the sole use of British English for teaching and evaluation purposes in the Nigerian ESL classroom thereby neglecting the local Nigerian variations which, as it should be expected, reflect the linguistic and cultural contexts that English must, as a necessary condition, accommodate if it must function effectively in Nigeria's multilingual socio-cultural setting. The study, after presenting some syntactic and lexico-semantic variations in Nigerian English and highlighting their appropriateness within the Nigerian socio-cultural context, argues that, if students must perform well in English and even in other subjects taught and examined in English, it is necessary to teach them and evaluate their performances by using an endonormative model (that is, Standard Nigerian English), which is capable of reflecting the local variations that English has, in a bid to satisfy the demands for communicative appropriateness, manifested in the Nigerian setting. This is so because Standard Nigerian English as an endonormative model is, because of its ability to appropriately reflect the Nigerian experience, more supportive to the students in the Nigerian ESL classroom than the foreign British model which, though used as the standard in Nigeria as a former British colony, is culturally inappropriate in the Nigerian context and does not, therefore, appeal to the sensibilities of the students who, in their quest for communicative appropriateness in English in the Nigerian socio-cultural setting, have to use the language to reflect the Nigerian worldview.
\end{abstract}

\section{Keywords}

Syntactic, Lexico-Semantic, Variation, Nigerian, Classroom

\section{Introduction}

English, Nigeria's official language, occupies a unique place in Nigerian education today. Not only has English

How to cite this paper: Okunrinmeta, U. (2014). Syntactic and Lexico-Semantic Variations in Nigerian English: Implications and Challenges in the ESL Classroom. Open Journal of Modern Linguistics, 4, 317-332.

http://dx.doi.org/10.4236/ojml.2014.42026 
been adopted as the principal medium of instruction in Nigeria's educational institutions but it has also been institutionalized as the language of educational evaluation in the Nigerian school system. It is stated in Section 3 paragraph 15 (4) of the National Policy on Education (1977, Revised: Federal Ministry of Education, 1981) that the mother tongue should be used as the language of instruction in pre-primary education and that every primary school child should be taught in his/her mother tongue or the language of his/her immediate community for the first three years, and thereafter in English. This implies that the mother tongue is to be used as the language of instruction at the early stages of the child's education, particularly at the pre-primary and lower primary levels, while English takes over from the mid-primary level to the university level. Fafunwa (1969) explains why the mother tongue or the language of the immediate community should be used as the language of instruction at the early stage of the child's education thus:

$\cdots$ if the Nigerian child is to be encouraged from the start to develop curiosity, manipulative ability, good spatial visualization, spontaneous flexibility, originality, initiative, industry, manual dexterity and mechanical comprehension, he should acquire these skills and attitudes through his mother tongue which is the most natural way to learn. This is the way the children in Europe and America learn.

Though the National Policy on Education makes a provision for the use of the Nigerian languages as media of instruction at the pre-primary and lower primary levels of the Nigerian school system, the arrangement is more in favour of English than the Nigerian languages. With this arrangement where English features as the dominant language of instruction and evaluation in Nigerian schools, especially from the mid-primary level to the tertiary level, English has automatically been given a very prestigious position in Nigeria's educational system and has, thus, been made to become more elevated than the Nigerian languages which, even after much struggle by such Nigerians as Fafunwa who favour the use of the mother tongue in the education of the Nigerian child, are only used reluctantly even at the early stage of the child's education. It is, therefore, not surprising that various efforts have, over the years, been made by various bodies and organizations, including the British Council, at improving the level of proficiency in English and the standard of teaching the subject at various levels of Nigeria's educational system. However, as Kujore (1995: p. 376) notes, it is alarming that, in spite of the tremendous functions that English performs as the language of educational instruction and evaluation in Nigeria and the bold efforts made over the years to encourage its effective teaching and learning, the vast majority of the learners record in recent years an appallingly low level of performance in the language, especially in public examinations. Okunrinmeta (2013b: p. 127) summarizes the situation thus:

-.. there has been a steady decline in the performance of students in English Language in the West African Senior School Certificate Examinations $\cdots$ between 1988 and 1992, the percentage of failure was high and consistent as it stood between $70 \%$ and $75 \%$ annually $\cdots$ in 1997 , only $6.54 \%$ of the candidates who took the examinations got credit passes in English Language, while nearly $67 \%$ had outright failure $\cdots$ only $29.59 \%$, $25.36 \%, 34.48 \%$ and $29.94 \%$ passed English Language at credit level $\cdots$ in 2004, 2005, 2006 and 2007 respectively $\cdots$ in $\cdots 2012 \cdots 38.1 \%$ of the candidates who sat for the examination had credits in at least five subjects, including English Language and Mathematics. This $\cdots$ was better than what was obtained in 2010 when only $23.71 \%$ passed at least five subjects, including English Language and Mathematics, at credit level, and in 2011 which recorded only $30.91 \%$.

This high rate of failure has been generally traced to various factors, including poor teaching method, nonavailability of qualified teachers, inappropriate course books and examination-oriented curriculum (Orji, 1987; Afolayan, 1995; Amuseghan, 2007; Adegbite, 2009; Okunrinmeta, 2008c, 2013b). However, one very important factor that has often been neglected is the sole use of foreign models, especially British English, for teaching and evaluation purposes in the Nigerian ESL classroom thereby neglecting the local Nigerian variations which, as it should be expected, reflect the linguistic and cultural contexts that English must, as a necessary condition, accommodate if it must function effectively in Nigeria's multilingual socio-cultural setting. As a former colony of Britain, Nigeria, just like many other countries in the Commonwealth, has adopted British English for all official purposes, including educational instruction and evaluation. This implies that all local Nigerian influences reflected in the English of Nigerians have to be treated as errors since they differ from what obtains in British English, which is widely considered as the "standard" that must be followed even in the Nigerian multilingual socio-cultural context where English is used as a second language (Okunrinmeta, 2013a: p. 31). Thus, if a pupil writes any Nigerian expression in an examination, it will, in spite of the fact that it reflects the Nigerian expe- 
rience and is, therefore, considered appropriate within the Nigerian context, be marked wrong by the examiner either because it does not reflect the native English culture or because it is not in the dictionary written preferably by a British author. According to Bamgbose (1995: pp. 25-26),

The problem that arises in ELT is the ambivalence that is demonstrated in the recognition of Nigerian usages and a reluctance to accept them in teaching and examinations $\cdots$ Examiners are even more conservative, for they reject even widespread usages as long as these cannot be found in standard grammars or dictionaries.

In such a situation, there is no way such a pupil can do well partly because the medium of instruction and evaluation is foreign to the knowledge of the world which influences the way he or she uses the language in the Nigerian setting and partly because the examiner often uses a wrong yardstick (British English, which is a metropolitan model that exists in an entirely different culture) (Uzoezie, 2004: p. 368), to judge the pupil's performance in the language in Nigeria's ESL situation. The situation is even made worse because of the fact that the abrupt switch from mother-tongue-based instruction from the lower primary level to a foreign medium (British English) from the mid-primary level upward puts many of the students in a state of imbalance which often affects their performance in the language and even in other subjects which are examined in English. It should be remarked that the child has a better chance of performing well both linguistically and academically when he or she is taught in the mother tongue. The effectiveness of the mother-tongue medium in the education of the Nigerian child has been demonstrated in the Ife Six-Year Primary Project (ISYPP) where the pupils in the experimental group who, according to Afolayan (1976) and Fafunwa, Macauley and Sokoya (1989), were taught all the subjects in the curriculum (except English) in the mother tongue demonstrated better competence in English than the control group and performed much better in practically all other subjects, including Science and Mathematics. This tremendous success demonstrates that the mother-tongue medium is more supportive to the Nigerian child than the English medium since its concepts reflect the culture of the people and are, therefore, familiar to the child. This is not so with the English-based instruction which tends to move the pupils from a familiar culture to an unfamiliar foreign culture, and this, consequently, affects their performance because of the sudden switch. Thus, rather than switching to the abstract, foreign British English based instruction, why can't we adopt a variety of English that will express the culture of the people with which the pupils are familiar? A variety which is still in full communion with its ancestral home but modified to suit its new Nigerian surroundings whose communicative realities it must reflect as an effective medium of communication and interaction? Must we, because we want to be loyal perpetually to our British colonial masters, adopt the British variety even when it is culturally inappropriate within the Nigerian setting? Must we import a foreign standard into our educational system even when we know that it does not appeal to the sensibilities and interests of the Nigerian ESL learner?

As Banjo (1975: p. 142) observed, it is "out of the question to import a Standard from outside" since the standard of English as a living language is to be found within the social context within which it is used for communication (see also Finegan, 2008: pp. 14-16; Akmajian, Demers, Farmer, \& Harnish, 2008: p. 283; Algeo, 2010: p. 195; Fromkin, Rodman, \& Hyams, 2011: p. 441). Mohammed (1995: p. 134) also notes that it would be inappropriate and counter-productive for educational institutions and examining bodies like WAEC (West African Examinations Council) to try to impose the native-speaker model of communicative competence in English on the Nigerian learner or to use it uncritically as a norm against which to evaluate his/her attainment in English, and that the teaching and examination syllabuses prescribed for Nigerian schools should not be normed against the communicative competence of the mythical native speaker but against that of the educated Nigerian. $\mathrm{He}$ maintains that the continued use of the native-speaker model of communicative competence as the sole means of evaluating performance in English by Nigerian students will only worsen their bad performance profile and should, therefore, be discontinued (1995: 147). What is, therefore, widely recommended for teaching and evaluation in Nigeria's educational system is an endonormative model. This model should, according to Afolayan (1988), ideally be World Standard English, modified by the local touch of the local Nigerian environment. This is necessary because, as Adeniran (1979: pp. 235-237) noted, though English is a world language,

$\cdots$ the people find it easier to identify with the standard evolved within their own linguistic culture and experience, and so strive for greater competence and more effective performance in what is practically their own regional variety of this world language $\cdots$ It is not a foreign but a second language with which the 
whole community can identify $\cdots$ Because that variety is not foreign to them, it does not prick their nationalistic sensibility $\cdots$ It can therefore be selected for detailed study and formalization, and be adopted as national standard.

Thus, as Dadzie (2004) observed, this endonormative model is more appropriate to the Nigerian situation than British English and its foreign-culture based course books which, because of their exclusive concentration on the native English culture, are today found to be grossly unsuitable for educational purposes in the Nigerian setting on account of their cultural inappropriateness, which makes Nigerians speak "like the book" and develop styles of writing which are stereotyped. Dadzie (2004: pp. 97-98) adds that until we begin to teach NE (Nigerian English), we will not be able to institutionalize it, and that it is only when we interpret the world through the eyes of Nigeria in a medium that is Nigeria that our children will understand what they learn better and express themselves with fluency and facility.

If the Nigerian learner of English must, therefore, do well in the language, it is necessary to use an endonormative model that is capable of reflecting the local variations that English has, in a bid to satisfy the demands for communicative appropriateness, manifested in the Nigerian setting. This is so because the model reflects the Nigerian experience, which makes its concepts more familiar to the Nigerian ESL learner (than the foreign concepts to which he or she is exposed through the sole medium of British English) and, thus, making the teaching/ learning of ESL in Nigeria easier and more refreshing. It is, therefore, against this background that this study seeks to review the syntactic and lexico-semantic variations manifested in the English of educated Nigerians so as to highlight their appropriateness within the Nigerian setting and discuss their implications and challenges in the Nigerian ESL classroom, especially with regard to how they can be effectively incorporated into the language teaching/learning process so as to assist the ESL learner to improve upon his or her performance in the language.

\section{A Review of Some Syntactic and Lexico-Semantic Variations in Nigerian English}

Nigerian English, according to Okunrinmeta (2013a: p. 30), is a regional variety of English spoken by Nigerians and it has identifiable features which distinguish it from other regional varieties of English, especially in terms of pronunciation, syntax and lexico-semantics. These features are, among many others, summarized as follows:

1) A reduced vowel system of seven simple vowels and six diphthongs, consonant substitution including the replacement of $/ \theta /$ and $/ \delta /$ with $/ \mathrm{t} /$ and $/ \mathrm{d} /$, complete devoicing of $/ \mathrm{z} /$ in inter- and post-vocalic positions, voicing of the alveolar stop when it occurs after voiceless sounds, deviant stress, a reduced intonation system with an inclination towards using the unidirectional tones (the falling and the rising tones) and non-differentiation in the length of vowels (Jibril, 1979; Kujore, 1985; Awonusi, 1986, 1987, 2004; Adetugbo, 1987, 2004; Udofot, 2004; Okunrinmeta, 2008c, 2009a);

2) A domestication of the meanings of such English words and expressions as "wife", "sorry", "welldone", "madam" and "share (a husband)", among others, to accommodate the contexts that the Nigerian languages and culture create for them in the Nigerian setting; the coining of words and expressions to appropriately reflect the Nigerian linguistic and socio-cultural situation so as to satisfy the quest for communicative appropriateness in English within the Nigerian context e.g. "head co-wife", "big mother", "second burial" and "son of the soil" and; idiomatic usage e.g. "to take in", "to put someone in the family way" and "to paddle one's own canoe" (Adegbija, 1989, 2004; Kujore, 1985, 1995; Jowitt, 1991; Banjo, 1995; Okunrinmeta, 2006, 2008a, 2008b, 2009b, 2013c) and;

3) The pluralization of non-count nouns, using stative verbs as dynamic verbs, substituting certain prepositions for others, using some prepositional verbs as non-prepositional verbs and vice versa, occurrence of the first person before the third person in a compound subject-NP, omission of the indefinite article and co-occurrence of possessives and demonstratives as pre-modifiers (Adekunle, 1979; Kujore, 1985; Jowitt, 1991; Okoro, 2004; Okunrinmeta, 2011, 2013a).

Adegbija (2004) argues that this domesticated variety of English in Nigeria is inevitable since there is no way Nigerians can use English effectively within the Nigerian linguistic and socio-cultural setting without, first of all, blending it with the Nigerian languages and culture which provide the contexts within which the language is used, interpreted and understood. The result of this linguistic and cultural blending is, therefore, the emergence of the Nigerian variety of English whose standard model, Standard Nigerian English (SNE), is recommended in this study for teaching and evaluation in Nigerian schools in the stead of British English. Adegbija (1989: p. 176) gives the advantages and the necessity for the adoption of this model thus: 
*. the nativisation of English in Nigeria could make the learning of English in the country much easier, particularly when taught by Nigerians. In other words, contrary to widely-held opinions and popular intuitions, in many parts of the world, the best teacher of a second language is not necessarily the native speaker but rather, a speaker versed in the local norms that the language has developed within the community in question. Hence, in view of the fact that English in Nigeria has developed its own $\cdots$ norms which are most suitable for the Nigerian $\cdots$ context, such norms are best encoded and decoded by Nigerians or foreigners brought up within the communicative norms of English in Nigeria.

This section reviews some of the syntactic and lexico-semantic variations manifested in the English usage of Nigerians with reference to such research studies as Bamgbose (1971), Adetugbo (1979), Kujore (1985, 1995), Adegbija (1989, 2004), Jowitt (1991), Okoro (2004), Bamiro (1994, 2006, 2009) and Okunrinmeta (2006, 2008a, 2008b, 2009b, 2010, 2011, 2012, 2013a, 2013c), which have proved that these Nigerian forms have been created, sustained and made meaningful by the Nigerian linguistic and cultural situation and should, therefore, be treated, not as errors, but as permissible local variations whose legitimacy and appropriateness within the Nigerian setting lie on their ability to reflect and express the Nigerian experience. Some of the lexico-semantic variations are summarized as follows:

- After-bride palmwine: a translation of the Igbo expression "nkwu ocha" or "nkwu elu", meaning "after-bride palmwine", which refers to the kegs of palmwine paid by the family of the groom (as part of the bride-price) to that of the bride, especially when the bride is "found at home" (that is, she is a virgin) and also when she is well-behaved.

- A finger cannot pick a louse from the head: a Nigerian proverb which emphasizes the importance attached to unity, co-operation and peaceful co-existence in bringing about development and progress in society. A finger is a metaphor for any isolated effort made by an individual which may, therefore, not succeed in producing the desired result and, thus, the need for all in the society to come together and work hard to ensure that the common goal of the society is achieved.

- Aso-ebi cloth: a special cloth used in Yorubaland in such special ceremonies as wedding, burial, naming etc.

- August break: the period during the rainy season, usually between early August and early September, when the rain stops temporarily, (perhaps for a month), before falling again. The period is often characterized by a drizzly weather accompanied by heavy winds which dry the water up.

- Banana peel: an event or action that teaches one to learn from the folly of others.

- Be a mosquito to somebody's ears: an idiomatic expression, meaning "be a constant source of disturbance to somebody", traceable to the Nigerian folktale which explains that the mosquito taunts the ear constantly just to fulfil its promise that whenever it (the mosquito) came across the ear (which once rejected its marriage proposal on account of its light nature and, thus, the possibility of being swept into the sea by the breeze), it would remind the ear that it (the mosquito) was still alive and not dead (Okunrinmeta, 2009b: p. 68).

- Bean cake: a kind of cake made from beans.

- Beat one's chest: an idiomatic expression, meaning "be bold enough to do or say something", traceable to the gorilla's habit of beating its chest to signify that it is bold enough to do anything to protect itself.

- Been-to/been-to-ness: someone who has returned to Nigeria from a long stay overseas. "Been-to-ness", therefore, describes the peculiar behaviour of the been-tos.

- Big madam: big madam is coined from "madam"-a term used in a derogatory sense to refer to a married woman who engages in love affairs with other men for financial gains. "Big madam" refers to a woman who was married but left her husband to engage openly in full-time love affairs with several men and collect money from them.

- Big man: a translation of "eni nla" (Yoruba), "opu kimi” (Izon) often used to refer to a wealthy and influential man; someone who is highly placed in society.

- Big mother: the most senior wife in a (polygamous) family and, thus, all the children in the family have to call her "mother" or "big mother".

- Black soap: a translation of "ọsẹ dudu" (Yoruba), a kind of soap, usually black in colour, made from ashes, palm oil, and some other ingredients, often used for bathing so as to ward off evil powers or spiritual attack.

- Bottom power: favours obtained by a woman through the use of feminine charm or the granting of sexual favours.

- Boy's quarters: outhouses or living quarters, detached from the main house, for "house boys" and "house 
girls" ("House boy" or "house girl" is the Nigerian version of house keeper or servant).

- Bride-price: the items, e.g. palmwine, gin, palm oil, yams, money etc., paid to a bride's family by the groom's family before a marriage can be contracted.

- Brother/sister: the son or daughter of the same parents, grandparents or great grandparents as another person; or a man or woman who comes from the same village, town or community as another person, especially when they meet, or live together, outside their village, town or community.

- Bunkerers: men engaged in bunkering (an illegal oil deal especially in the Niger Delta) and the women who, through the love affairs they have with such men, have a share of the money derived from the illegal deal.

- Bush meat: a translation of "ẹran igbẹ" (Yoruba) or "anu ohia" (Igbo), which refers to "any edible animal caught from the bush (game)".

- Cash madam: an excessively rich woman socialite who flaunts her wealth.

- Check out: run away from Nigeria, as a result of its economic hardships, to seek succour and refuge in other countries.

- Chewing stick: translated from "pako" (Yoruba), "dụwọ̣n" (Izon), describing "a slim, slender stick chewed for cleaning or brushing the teeth".

- Concoction: rice cooked with pepper, salt, palm oil and onion.

- Co-outfit: party outfit usually worn by the members of a social group for identification.

- Cover cloth: a long piece of cloth (of about six yards or more) wrapped around the body while one sleeps, and may continue to be worn after one has got up prior to bathing and dressing. It therefore serves conveniently as sheet, pyjamas and dressing gown.

- Cross to the other side of the river: be dead. It is a translation of the Izon expression, "una kiri bẹin", often used, interpreted and understood within the context of the belief that the living and the dead are separated by a wide, deep river. Thus, it is only when a person dies that he/she can cross over to the other side.

- Cut your coat according to your size: a Nigerian saying meaning "do things that are within your power or control". This is different from "cut your coat according to your cloth", meaning, let the size of your expenditure be determined by the size of your resources, which looks at things from the economic perspective. Thus, the former is more general than the latter in terms of application.

- Don't pour sand into my garri: "Garri" refers to "cassava flour processed by filtering, drying and frying". The idiom, "to pour sand into someone's garri" therefore means "to put someone into trouble", or "to implicate someone", or "to ruin someone's chances". Thus, "don't pour sand into my garri" is often said as a form of warning to others "not to put one into trouble or to implicate one or to ruin one's chances".

- Drag someone's name in the mud: the "mud" is a metaphor for stain, discredit and shame to one's personality. The expression, "(to) drag someone's name in the mud" means "to deliberately do things that put someone in shame and disgrace".

- Ease oneself: a polite expression in Nigerian English usage meaning "defecate".

- Even if the bead is not long enough to go round the neck, it can still be used to tie the wrist: a Nigerian proverb which lauds prudent management of resources and discourages wastefulness by urging people to make good use of whatever they have, no matter how small or little it is.

- Father/mother: "Father" refers to one's male parent; the brother of one's father or the husband of the sister of one's father or mother especially when he plays the role of a father in one's life; or any elderly man who is as old as, or older than, one's father. In some cases, the eldest man in the family may be addressed as "father" by all in the family, including his younger brothers and sisters, especially when the age difference between them is much. "Mother", just like "father", refers to one's female parent, or a woman who has adopted a child; the sister of one's father or mother, or the wife of one's father or uncle who plays a motherly role in one's life; or any elderly woman who is of one's mother's age or older than one's mother. The eldest woman in the family may, in some cases, be addressed as "mother" by all in the family, including her younger brothers and sisters, especially when the age difference between them is much.

- Fathers/mothers of the day: important father-like or mother-like figures, especially on a wedding occasion.

- Fire-brigade approach: "Fire-brigade approach", derived from the uncoordinated activities of the Nigerian Fire Service which, perhaps because of its ill-equipped nature, is known for its inability to prepare adequately in advance for any fire outbreak, is a metaphor for inadequate preparation or planning and, thus, anything done without adequate preparation or planning has been given a "fire-brigade approach".

- Four-one-nine: coined from section 419 of the Criminal Code of Nigeria which deals with various forms of 
financial and economic crimes in Nigeria. Thus, anyone who engages in on-line fraud or any other financial or economic crime outlined in this section of the Criminal Code is referred to in the Nigerian context as a "four-one-nine", meaning a "dupe".

- Ghost (as in "ghostworker"): a worker who earns salaries and enjoys other benefits of office even though he/she does not exist.

- God-father: a "money bag" (a very wealthy person) that sponsors a politician for an elective position and, thus, controls the politician's activities after he or she must have succeeded in getting the position (Note also "god-fatherism", the practice of having, or becoming, a "god-father").

- Go on a dog's errand: a direct translation of the local idiom, "obiri ikọ wọnị", which means "doing something which is contrary to what one was sent to do".

- Go-slow (as in "to get involved in a go-slow transaction"): a Nigerian expression for "traffic jam"; a situation where vehicles are expected to move very slowly because of traffic congestion. In the Nigerian setting, whenever there is a "go-slow", hawkers often use the opportunity to sell their wares and, therefore, the expression, a "go-slow transaction", meaning a transaction made in a "go-slow", which, as it should be expected, involves so many risks. For example, a dubious seller may, as Okunrinmeta (2012: p. 227) noted, take an undue advantage of the situation to sell sub-standard goods to the buyer since he/she does not have the opportunity to properly examine what he/she is buying. Similarly, the seller may, in some cases, lose his/her money in the process because the buyer may, after collecting the item from the seller, refuse to throw the money down when the vehicle moves fast and the seller is unable to catch up with it. It is, therefore, a transaction involving risks. This therefore provides the context within which the expression, "to get involved in a go-slow transaction", is used to mean "getting involved in an uncertain and risky undertaking".

- Have hooks in one's fingers and toes: be clever at stealing or picking other people's belongings; a reflection of what happened in a folktale where the cat visited its friends (the lion, the tiger and the squirrel) and used the hooks mysteriously fixed to its fingers and toes to "hook up" all the precious belongings of the animals it visited.

- He who closes the door does not close the ears: often used at the end of a speech or announcement to draw attention to the importance and urgency attached to what has been said thereby jolting the hearer to respond immediately to it.

- Head co-wife/junior co-wives: "Head co-wife" refers to the most senior of all the women married to the members of a family. She can, therefore, refer to all the remaining wives in the family as her "junior cowives" because they all met her there.

- Head-tie: headgear or headdress. The analogy, "head-tie", is a consequence of the fact that this kind of costume involves "tying" a dress or cloth around the head.

- Hold the walking stick: The "walking stick" is a metaphor for old age since it is known to be associated with the old people who hold it so as to support themselves while walking. "To hold the walking stick", therefore, means to become very old.

- Hot drink: (usually shortened as "hot") refers to hard liquor such as whisky, gin and brandy.

- How do you do: The use of "how do you do?" as well as the response it elicits has, within the Nigerian cultural context, been affected by the Nigerian culture which demands that elders be respected. The use of "how do you do?" has become restricted by age considerations since it can only be used when the person being addressed is younger than, or is within the same age grade as, the speaker. If the person being addressed is older than the speaker, its use is seriously frowned at because it connotes rudeness. Similarly, the response to "how do you do?", which is usually "how do you do?", especially in native English contexts, has been modified in a bid to show respect as demanded by the Nigerian culture. Thus, "how do you do?", when uttered especially by an elderly person, normally elicits the response "fine", which is generally considered within the Nigerian cultural context as more polite than the repetition of "how do you do?" in response which rather suggests rudeness. Thus, as Okunrinmeta (2009b: p. 59) noted, even if a Nigerian knows that the response to "how do you do?" within the English culture is "how do you do?", he/she has to say "fine" within the Nigerian culture to satisfy the demands that the culture imposes on him/her.

- Husband/wife: In the Nigerian context, husband refers not only to the man to whom a woman is married, but also to what is generally described as "cultural husbands". The term is often used in three major contexts: "the brothers or sisters of one's husband", "the townsmen of one's husband, especially when they live together outside their village, town or community", and "any child that was born long before the arrival of a 
woman into her husband's family". This is so because all of them, including the young child born long before the woman was married into the family, usually take up the cultural responsibility of representing the husband and taking care of her whenever he (the "real husband") is not around. They can, therefore, refer to her as their wife within this cultural context. Thus, wife refers not only to one's personal wife, but also to the wife or wives of one's brothers and those of one's townsmen, especially when living together outside the village, town or community.

- Introduction: a first formal meeting between parents or relations of a bride and groom in which the groom's marriage intentions are declared and his candidacy formally announced.

- Ladies of the wardrobe: important ladies working behind the scenes in a wedding occasion.

- Let someone die before burying him/her: not to interrupt a person while he/she is speaking.

- Lick an orange/suck an orange: a variant of SBE "eat an orange", and a translation of "ogụn taba" (Izon) or "mu ọsan" (Yoruba), coined to describe what happens in the Nigerian socio-cultural setting where oranges are peeled and cut into two halves before their juice is licked and sucked.

- Little husband: any child, male or female, who was born into the husband's family long before the arrival of a woman into her husband's home.

- Little wife: the wife of one's brother or of one's townsman who is far younger than one; or a little girl of between seven and twelve who is given to a man for a wife but cannot marry him at the moment because of her age.

- Manpower: drugs/herbs that enhance male sexual performance. This context of "manpower" is made appropriate within the Nigerian context by the Nigerian polygamous marriage system which permits a man to marry, not only one wife as it is in the native English cultural setting, but also two or more wives. Since he has to satisfy them sexually, there is the need to use performance enhancement herbs/drugs. Thus, the term "manpower" has been coined to describe the herbs/drugs a man takes so as to have enough sexual "power" to satisfy his wives.

- Meet somebody well: used as an invitation, when one is visited while eating, to invite a visitor to partake in a meal.

- More grease to your elbow: often uttered as a way of encouraging someone to work or struggle harder; or as a way of congratulating someone who has achieved success in one way or the other.

- National cake: that portion of Nigeria's wealth which Nigerians acquire especially through illegal and fraudulent means.

- Not on seat: used when an official is not available in his/her office. However, when the official is available, we say "he/she is on seat".

- Open the floor: describes a party situation whereby the chairman of the occasion is given the privilege to dance before other people are allowed to dance.

- Owner's corner: a corner in the back seat of a chauffeur-driven car, (at right angles to the chauffeur), reserved exclusively for the owner of the vehicle, the boss or a top-notch functionary in the public service or business circles. Perhaps, this is just to, as characteristic of all "big men" in Nigeria, prove "big" in the sense that they are of a higher social status and should, therefore, be distinguished (as the owner of the car) from the chauffeur.

- Paddle one's own canoe: an idiomatic expression used in the Nigerian setting not only in the sense of "depending on oneself", but also in the sense of telling one "not to interfere with another person's affair".

- Pepper soup: soup prepared with red pepper and other condiments to give it a hot and spicy flavour.

- Play on someone's intelligence: an idiomatic expression meaning "try to deceive someone".

- Pounded yam: yam pounded or mashed with a pestle and a mortar.

- Private practice: any extra or additional means of getting income besides one's regular employment so as to cushion the effect of the biting economic situation in Nigeria.

- Put in the family way: (to) make a woman pregnant.

- Put to bed: (to) give birth to a baby.

- Rehearse the cock's foolishness: behave in such a way as to endanger one's life.

- Resource control: a traditional shirt ("amayanabo") designed in such a manner that a golden chain links the neck of the shirt to its breast pocket. The chain has a golden button inserted into the button hole on the neck of the shirt while the rest of the chain flows downwards into the breast pocket of the shirt in a "controlled manner". This shirt, which is now worn generally by the people of the Niger Delta Region of Nigeria, is of- 
ten labelled as resource control because of the leading role that the Niger Deltans play in the resource control struggle where the Federal Government of Nigeria is, because of its criminal neglect of the region, told to allow the people of the Niger Delta to control their resources.

- Second burial: This is coined to reflect the Nigerian cultural situation where two stages of burial, especially when it involves an old person, are often recognised: the first burial and the second burial. The first burial takes place when the body of the deceased is actually buried immediately after death. The burial ceremony at this stage is not elaborate. The second burial, on the other hand, is an important social occasion, where the death of the deceased is formally observed by the whole community, and it often comes up after the first burial and, thus, the term "second burial". Since there is usually heavy expenditure on food, drink and entertainment generally as it involves various forms of traditional display, the children of the deceased and other family members are often given enough time to plan it. The second burial, as a final burial rite for the deceased, is highly valued among Nigerians because it is often seen as proof that the deceased took good care of his/her children and, thus, they must pay him/her back by sending him/her to the world beyond in an honourable way. Thus, without this burial, the funeral rites for the deceased are often considered incomplete and, thus, dishonourable.

- Senior/junior brother/sister: "Senior" (as in "senior brother" or "senior sister") and "junior" (as in "junior brother" or "junior sister") are used to reflect the age and numerical position of each brother or sister in the family. Thus, "senior" in this context describes one's brother or sister who is "higher" than one in terms of age and numerical position in the family, while "junior" describes one's brother or sister who is "lower" than one in terms of age and numerical position. "Senior brother" or "senior sister", therefore, means "one's brother or sister that is older than one". Thus, "senior brother" is a variant of "elder brother", while "senior sister" is equivalent to "elder sister". "Junior brother" or "junior sister", on the other hand, refers to "one's brother or sister whose age or position in the family is below one's age or position". Thus, "junior brother" and "junior sister" are variants of "younger brother" and "younger sister" respectively.

- Senior wife/junior wife: "senior wife" refers to the first wife in a polygamous family, while "junior wife" refers to the second wife, especially where there are only two wives in the family.

- Share a husband: (of two or more women) to marry the same husband whom they share among themselves and take care of in turns, perhaps, on a weekly basis.

- Small wife: often used, especially where there are more than two wives in the family, to distinguish the "most junior wife" from the remaining "senior co-wives" (the wives the most junior wife met in the husband's house).

- Smell pepper: face a tough time or be given a rough deal.

- Socialite: a person who is fond of associating with people especially to the extent of belonging to a group.

- Social wake-keeping: staying awake for some time during or throughout the night in honour of a dead person.

- Son/daughter: Besides the basic meaning of being "the male child of a parent"/“the female child of a parent", the meaning of "son"/“daughter" has, because of the Nigerian extended family structure and the general brotherly feeling prevalent among Nigerians, been extended to refer to "the son/daughter of one's brother, first cousin or second cousin", or "any boy/girl or man/woman in the community that is within one's son's/ daughter's age grade".

- Son of the soil: the free-born of a particular town or community.

- Sorry: used not only for apologizing for a wrong done as it is in native English contexts, but also as a form of greeting to console or sympathize with someone who has suffered misfortune or harm. It is often used in the Nigerian context to greet someone who is bereaved, or someone involved in an accident, or even someone who sneezes, trips etc., even when the speaker is not responsible for what happened and, thus, it reflects the Nigerian culture which demands that we show sympathy to our neighbours and console them when they are in distress so as to lessen their burden.

- Split open the crocodile's intestine: reveal a secret.

- Take in: become pregnant.

- The head of the family-head is a refuse dump: The "head of the family-head" is a metaphor for anyone holding a leadership position. Thus, the proverb serves as a form of encouragement to those in leadership positions to forge ahead despite the expected impediments that may come their way in the course of performing their leadership responsibilities. It also reminds every leader of the fact that the role he/she plays is that 
which requires selfless devotion and sacrifice and, thus, he/she should be prepared to endure any misfortune that may be suffered in the course of performing this responsibility.

- The sick is a slave to the medicine man: used as a form of consolation for those who are helpless and are, therefore, at the mercy of other people who usually oppress or exploit them because of their condition.

- The taste of the pudding is the eating: a variant of British English "the proof of the pudding is in the eating".

- Traditional/customary wedding: any wedding contracted mainly according to native customs.

- True son (of one's father): used to refer to a person who arrives when something concerning him is being discussed.

- Uncle/aunt: "Uncle"/“aunt", within the English culture, means "the brother/sister of one's father or mother, or husband/wife of one's aunt/uncle". This context of "uncle"/“aunt" is also applicable in the Nigerian setting. However, Nigerians have also used "uncle"/"aunt" in the Nigerian cultural context to refer to "any elderly man/woman who could not, because of his/her age, be called by name". He/she is, therefore, generally called "uncle"/"aunt" despite the fact that he/she is not one's blood relation and, thus, he/she becomes a "general uncle/aunt" in the Nigerian sense.

- Use a lady: use her to achieve some immoral ends; or use her for "money-making rituals" by having sex with her.

- Use medicine: use magical powers to achieve an end.

- Welldone: used in the Nigerian context not only to praise someone for the work or feat he or she has already accomplished as it is in the native English context, but also as a form of greeting to someone engaged in any form of work or activity. e.g. playing draughts, washing clothes etc. It may also be used as a form of casual greeting for somebody who is not even working at all. If, for example, a man passes by and sees two or three people sitting outside, he may wave them and say "well done" as a way of greeting them casually.

- White soup: soup prepared without palm oil or vegetable oil.

- Wrapper: a piece of cloth (of about two yards or more) tied around the waist of women, covering the parts between the waist and the ankles.

- Yam flower: a kind of flower made from yam.

- You may cut off my two legs if you ever find them here: a direct translation of the Igbo expression, "i tu m ebe a ozọ, gbu jie m ukwu", which is often said in the Nigerian setting, especially when one's advice is turned down.

The lexico-semantic variations presented above are largely found to be deeply rooted in the cultural practices and beliefs of the Nigerian people and are, therefore, considered appropriate within the Nigerian context because they reflect the Nigerian socio-cultural experience. Thus, they have been accepted and treated as permissible local variations whose appropriateness and legitimacy are strongly founded on the cultural patterns of the Nigerian people and are, therefore, in conformity with their worldview. Since they occur frequently in the English usage of the majority of educated Nigerians and, therefore, constitute acceptable standard usage within the Nigerian setting, they form a considerable portion of the endonormative model recommended for teaching and educational evaluation in this study.

There are also some variations in the area of syntax. However, owing to limitations in terms of space, just a few of them are summarised below:

- The pluralisation of some non-count nouns e.g. "These behaviours are not good" (Okunrinmeta, 2013a: p. 35).

- The use of such stative verbs as "hear" and "see" as dynamic verbs e.g. "Excuse me, sir, we are not hearing you!"' (Okoro, 2004: p. 171).

- The substitution of certain prepositions for others e.g. "Meanwhile, I congratulated him for his brilliant performance on the stage in Zulu's play recently, and also advised him to completely hands off the matter of Tunde's grandmother's estate" (Kujore, 1995: p. 373).

- Using some prepositional verbs as non-prepositional verbs e.g. "One other point that can be used to buttress what Chief Okpoka has said is that Egbesu is the god of war and peace" (Okunrinmeta, 2011: p. 221).

- The treatment of some non-prepositional verbs as prepositional verbs e.g. "They discussed about many problems" (Jowitt, 1991: p. 116).

- The occurrence of the first person before the third person in the structure of a compound subject-NP e.g. "I and my brother will come" (Adekunle, 1979: p. 33).

Okunrinmeta $(2011,2013 a)$ note that these variant syntactic forms, though different from what occurs espe- 
cially in British English, have been accepted and treated as permissible local variations within the Nigerian linguistic and socio-cultural context for various reasons. One, they are appropriate within the Nigerian context because they reflect what happens in the Nigerian languages and, thus, the preferences which Nigerians have for similar structures in the Nigerian languages. For example, the pluralisation of such non-count nouns as "behaviour", "information", "hair" and "dress" as count nouns in the English of Nigerians is, according to Okunrinmeta (2013a: pp. 34-35), traceable to the Nigerian languages where such nouns are actually classified and treated as count nouns and, thus, they exhibit all the distinguishing features of count nouns in the Nigerian languages. Similarly, the use of such prepositional verbs as "buttress" as non-prepositional verbs in the English of Nigerians, and such non-prepositional verbs as "discuss" as prepositional verbs, reflect the Nigerian languages where they are treated as non-prepositional verbs and prepositional verbs respectively. Also, the preference for certain prepositions in some syntactic environments where, in British English, for example, some other prepositions are preferred, (e.g. "congratulate for" instead of "congratulate on"), is traceable to the fact that these verbs (or their equivalents) in the Nigerian languages usually co-occur with the prepositions which the Nigerian speakers use along with them in their English (see Okunrinmeta, 2011: p. 221). All these syntactic forms are, therefore, generally considered appropriate within the Nigerian setting because they reflect the preferred patterns in the Nigerian languages. Two, they are not ungrammatical since they do not violate any serious syntactic rule in English but merely reflect a departure from the preferences given to certain structures in some native-English contexts. For example, the preference for the occurrence of the third person before the first person in the structure of a compound subject-NP in native English contexts is, as Quirk et al. (2003: p. 338) suggest, borne out of the desire to obey the rule of politeness in English which stipulates that first person pronouns should occur at the end of a coordinate construction. However, this preferred order in native English contexts is not preferred in the Nigerian English context where the first person is made to occur before the third person in a bid to appropriately reflect the preferred structural pattern in the Nigerian languages. If this preferred order in native English contexts is not preferred by the Nigerian speaker who uses the English language within the Nigerian linguistic and cultural setting, the resultant variation should not be seen as an error but as a mere shift from the preferred order in native English contexts. Thus, as Adekunle (1979: p. 33) argued, such an MT-induced structure as "I and my brother will come" (which is often condemned as an error simply because it is different from the British English form, "My brother and I will come"), should be accepted as a permissible local variation because, though the structure is unconventional, it is not ungrammatical but merely reflects the favourite pattern in the Nigerian languages. Three, they are intelligible especially within the Nigerian setting. In fact, some of them provide additional contexts of usage to the English language in Nigeria's linguistic and socio-cultural setting by reflecting the full range of meaning that their equivalents in the Nigerian languages are capable of expressing. For example, such stative verbs as "see" and "hear" are, as observed by Okunrinmeta (2011: p. 224), used both in the stative and dynamic senses so as to differentiate the two shades of meaning they are capable of expressing in the Nigerian languages: "I am seeing you" (I am seeing (looking at) you at the moment) and "I can see you" (I am not blind and can, therefore, see you) on the one hand, and "I am hearing you" (I am hearing what you are saying at the moment) and "I can hear you" (I am not deaf and can, therefore, hear what you are saying), on the other. This would have been impossible if they had been used only as stative verbs as prescribed especially by the native (British) English speakers. Four, they occur frequently in the English of the majority of educated (Nigerian) English speakers. Besides, they are similar to some American English variations that are today accepted as standard usage both within and outside the American setting (see Kujore, 1995: p. 369). For example, we have in Standard American English usage instances of pluralisation of non-count nouns (e.g. accommodation: accommodations) as well as variations in prepositional usage (e.g. "aim to (do something)" instead of British English "aim at (doing something)" and "to protest" instead of British English "to protest at/over/against"). If these syntactic forms manifested in the English of Nigerians are similar to some American English variations accepted as standard usage both within and outside the American setting, then, it is unfair to treat them as errors, especially in the English of the Nigerian learners who use the language within Nigeria's socio-cultural setting and must, therefore, reflect its realities in their English usage so as to satisfy the demands of communicative appropriateness.

\section{Implications and Challenges in the Nigerian ESL Classroom}

The syntactic and lexico-semantic forms presented in this study are considered appropriate within the Nigerian 
linguistic and cultural setting because of their ability to effectively reflect and express the Nigerian experience. Since their appropriateness and legitimacy within the Nigerian socio-cultural setting have been attested to by quite a number of studies on the Nigerian language-contact situation (including Bamgbose, 1971; Adegbija, 1989; Jowitt, 1991; Okunrinmeta, 2009b, 2011, 2012, 2013a, among many others) and have, therefore, been accepted as permissible local variations within the Nigerian context, they should be taught in Nigerian schools alongside all other Nigerian variations which appropriately reflect the Nigerian socio-cultural experience and should, therefore, form a considerable part of the endonormative model recommended here. This, if done, will enable the learners of English in Nigeria's ESL situation to be exposed to the English language, not exactly as it is prescribed in the dictionary compiled by Britons or Americans who do not know or appreciate the contexts which the Nigerian culture creates for the language in the Nigerian setting, but as it is actually used by Nigerians to suit local conditions, to express local experiences and to cater for the local needs of the local Nigerian environment. This is, therefore, the first bold step that should be taken towards satisfying the yearning of Nigerians for communicative appropriateness in English and, thus, the clamour for the use of an endonormative model of English in Nigeria.

However, the challenges arising from the negative attitudes of teachers towards Nigerian expressions in the ESL classroom have to be urgently addressed since they, if not properly taken care of, will continue to be a threat to the effective teaching of these variations in the ESL classroom and, by extension, a setback to the endorsement and use of an endonormative model for educational instruction and evaluation in Nigeria. To enhance the legitimacy of these variations within the Nigerian setting, where some teachers strongly feel that, in spite of the fact that the variations reflect the Nigerian experience and are, therefore, found to be appropriate within the Nigerian context and, thus, constitute acceptable standard usage especially in the Nigerian socio-cultural setting, they cannot be used for educational purposes simply because they differ from what obtains in British English, there is the urgent need to update all existing Nigerian English dictionaries, including Igboanusi (2001), to reflect the variations and highlight the contexts in which they are used. There is also the need to update the Nigerian component of the International Corpus of English (ICE) project so as to include these variations thereby giving them wider publicity and, thus, solving the problem of international intelligibility envisaged by some people who fear that the use of an endonormative model, with its full Nigerian linguistic and cultural coloration, may cause intelligibility problems at the level of international communication. If these syntactic and lexico-semantic variations are incorporated into the ICE project, it will project not only the sumptuous Nigerian flavour given to English usage in the Nigerian socio-cultural context but will also put an end to the doubts that some people, especially in the Nigerian setting, cast on the appropriateness of these variations and will, therefore, enhance their acceptability and frequency of use both within and outside the Nigerian socio-cultural setting.

Besides, there is the need to launch a massive awareness campaign on the relationship between language and culture in the Nigerian setting so as to call attention to the fact that the way English is used in the Nigerian culture cannot be exactly the same as it is used especially in the native British contexts which are indicated in the dictionary. Thus, even if an expression in the English of Nigerians is not found in the dictionary, such an expression should not be condemned as an error but should be considered and accepted as a variant especially if it reflects the Nigerian socio-cultural experience and is, therefore, considered appropriate within the Nigerian socio-cultural context by the majority of educated Nigerian English speakers. Seminars and workshops should, therefore, be organized regularly to enlighten people on the appropriateness of these culturally-induced variations manifested in the English of Nigerian speakers thereby emphasizing the need to have a positive attitude towards them.

Similarly, more emphasis should be placed on cultural education so as to enhance creativity in language use. Though this is done in most Nigerian schools, especially through the teaching/use of the mother tongue/language of the immediate environment emphasised in the primary school curriculum as well as the emphasis placed on the teaching of the Nigerian languages in Nigeria's secondary and tertiary institutions, compliance should be more effectively enforced in all Nigerian schools-whether public or private. If more emphasis is placed on cultural education in Nigerian schools, and the Nigerian languages and culture-based courses are effectively taught, the learners will be well exposed to various aspects of the culture of the Nigerian people thereby facilitating their acquisition of the relevant cultural knowledge required for the creative use of language in the Nigerian socio-cultural setting.

Finally, there is the need to design an appropriate pedagogical approach that can be effectively used to teach the endonormative model of English recommended in this study with all its local linguistic and cultural colora- 
tion. For example, when teaching the lexico-semantic and syntactic variations in this Nigerian model of English, it is necessary that they are traced to their cultural roots so as to situate them within the strong cultural foundation that provides the contexts within which they are used, interpreted and understood. As this is done, these Nigerian variations should also be compared to their British counterparts, if there are any. For example, the idiom, "to split open the crocodile's intestine" (meaning, "to reveal a secret"), can be taught in the Nigerian ESL classroom alongside the British English form, "to let the cat out of the bag", which, though inappropriate in the Nigerian cultural context, is what is taught in the Nigerian ESL classroom. According to Okunrinmeta (2009b), "to split open the crocodile's intestine" is more appropriate and, thus, preferred within the Nigerian context to the British English variant "to let the cat out of the bag" because it is situated within a strong cultural belief in the Nigerian socio-cultural setting. The crocodile is a scarce amphibious carnivore which, as it is believed in the riverine setting, is difficult to find and kill. It is, therefore, strongly believed that whatever that is inside the crocodile's intestine is a "top secret" since nobody knows what is there. The crocodile's intestine is, therefore, a metaphor for secrecy. Based on this, it is believed within the Nigerian cultural setting that the intestine of the crocodile, which is expected to contain many "strange" things including parts of the human body like the hair, teeth, finger-nails etc., should not be "split open" in the public, especially in the presence of children, because no one knows what will be found in it. Thus, "to split open the crocodile's intestine" has, within the Nigerian sociocultural context, become an acceptable, and a more preferred, variant of the English idiom "to let the cat out of the bag", which is considered inappropriate in the Nigerian socio-cultural context because it is contrary to the Nigerian worldview in the sense that it does not reflect what actually happens in the Nigerian socio-cultural setting where cats are, especially when they are newly bought, put in an "ite" or "iyama" (a locally-made fish cage), and not in a bag. Besides, the "ite" or "iyama" which, within the Nigerian riverine setting, performs the function of the "bag" in the idiom "to let the cat out of the bag" has nothing secret in it since what is inside it is clearly seen by everyone (Okunrinmeta, 2009b: p. 66). Thus, comparing the Nigerian variations to their British counterparts in the course of teaching serves two major purposes. One, it is aimed at putting in the limelight the appropriateness of the Nigerian variants and, by extension, the inappropriateness of the British variants in the Nigerian socio-cultural context thereby making the learners to develop strong faith in the ability of the Nigerian variants to appropriately reflect and express the Nigerian socio-cultural experience. Two, the fact that the Nigerian variants are compared to the British variants in the course of teaching makes it possible for the Nigerian learners of English to be exposed to, at least, two varieties of English at the same time thereby making them to be bidialectal and, thus, equipping them with the communicative competence required to switch from one dialect to the other depending on the situation and context of use.

On the other hand, where the syntactic and lexico-semantic forms manifested in the English of Nigerian speakers are seen, not as variants, but as errors, the need to design an effective pedagogical approach to tackle these errors, which are usually caused by inadequate exposure, becomes doubly necessary. To this end, this study recommends that the error should, first of all, be traced to the source language so as to explain why it is considered as an error in English even within the Nigerian setting. This will, at least, draw the attention of the learners to such errors and, thus, guide them (the learners) to correct or avoid them. This was what was done in Okunrinmeta (2013b) where, for example, the error arising from the substitution of "their selfs" or "their selves" for "themselves" as the plural of "himself", "herself" and "itself" was traced to the Izon language where all reflexive pronouns are derived by adding "ozu" (self) to the possessive forms of the pronouns e.g. "ẹni ozu" (my self), "inị ozu" (your self), "wọnị ozu" (our self), "ọnị ozu" (their self), "unị ozu" (his self) and "anị ozu" (her self) (see also Okunrinmeta, 2011: pp. 219-220). Since "them" is an object pronoun, it is incorrect in Izon to say "ọ ozu" (themself). This is why "ọnị ozu" (their self) and its plural "ọnị aozu" (their selves) are preferred in Izon. In English, just like in Izon, the reflexive pronouns "myself: ourselves" and "yourself : yourselves" are derived by adding "-self" to the possessive forms "my", "our" and "your". But, unlike what obtains in Izon, the third person singular reflexive pronouns "himself", "herself" and "itself", as well as the third person plural reflexive pronoun "themselves", are formed by adding "-self" to the object forms "him", "her" ("her" may also be used as a possessive pronoun), "it" and "them". This therefore explains why it is wrong to have "their selfs" or "their selves" as the plural of "himself", "herself" and "itself", instead of "themselves".

\section{Conclusion}

English usage in the Nigerian socio-cultural setting, as it is reflected in the syntactic and lexico-semantic varia- 
tions highlighted in this study, has been given a distinctive Nigerian coloration so as to enable it to effectively reflect the Nigerian situation. This is an indication that, for the language to function effectively in the Nigerian ESL setting, it must, as a necessary condition, go beyond the confines of the native (British) English culture to blend with the Nigerian languages and culture and to accommodate and express the various Nigerian socio-cultural experiences which, though unknown in the native English cultural context, are present in the Nigerian cultural setting and must, therefore, be appropriately reflected in English so as to satisfy the demands of communicative appropriateness within the Nigerian socio-cultural context. This implies that the effective use of English by Nigerians should be dictated, not by their ability to use the language to reflect exclusively the contexts provided in the dictionaries written especially by British authors, but by their ability to reflect in their English usage the Nigerian experience. This also implies that the performance of Nigerians in English should be evaluated in terms of their ability to adapt the language to suit local conditions, to express local experiences and to cater for the local needs of the local Nigerian environment. This therefore forms the basis on which the study recommends that, if Nigerian students should do well in English in the Nigerian ESL classroom, they should be taught and evaluated in an endonormative model (Standard Nigerian English) and not in British English whose concepts are foreign to the Nigerian culture which provides the contexts within which the language is used, interpreted and understood in the Nigerian socio-cultural setting. This is the only way the Nigerian ESL learner can be assisted to improve upon his or her performance in the language. Until this is done, the vast majority of the learners will continue to record an appallingly low level of performance in English, especially in public examinations.

\section{References}

Adegbija, E. (1989). Lexico-Semantic Variation in Nigerian English. World Englishes, 8, 165-177. http://dx.doi.org/10.1111/j.1467-971X.1989.tb00652.x

Adegbija, E. (2004). The Domestication of English in Nigeria. In S. Awonusi, \& E. A. Babalola (Eds.), The Domestication of English in Nigeria: A Festschrift in Honour of Abiodun Adetugbo (pp. 20-44). Lagos: University of Lagos Press.

Adegbite, W. (2009). The Psycholinguistics of English Language in Nigeria. Ibadan: Kraft Books.

Adekunle, M. A. (1979). Non-Random Variation in the Nigeria English. In E. Ubahakwe (Ed.), Varieties and Functions of English in Nigeria (pp. 27-42). Ibadan: African Universities Press.

Adeniran, A. (1979). Nigerian Elite English as a Model of Nigerian English. In E. Ubahakwe (Ed.), Varieties and Functions of English in Nigeria (pp. 227-241). Ibadan: African Universities Press.

Adetugbo, A. (1979). Nigerian English and Communicative Competence. In E. Ubahakwe (Ed.), Varieties and Functions of English in Nigeria (pp. 167-183). Ibadan: African Universities Press.

Adetugbo, A. (1987). Nigerian English Phonology: Is There Any Standard? Lagos Review of English Studies, IX, 64-84.

Adetugbo, A. (2004). Problems of Standardisation and Nigerian English Phonology. In A. B. K. Dadzi, \& S. Awonusi (Eds.), Nigerian English: Influences and Characteristics (pp. 179-199). Lagos: Concept Publications.

Afolayan, A. (1976). The Six-Year Primary Project in Nigeria. In A. Bamgbose (Ed.), Mother-Tongue Education: The West African Experience (pp. 133-134). London: Hodder and Stoughton.

Afolayan, A. (1988). Teaching English as a Second Language to Adult Learners. In J. A. Akinpelu, J. T. Okara, \& M. A. Omolewa (Eds.), Language and Adult Education: Essays in memory of S.H.O. Tomori, Ibadan: Ibadan University Press.

Afolayan, A. (1995). Ineffectiveness in the Presentation of English in Nigeria: Sources and Remedies. In A. Bamgbose, A. Banjo, \& A. Thomas (Eds.), New Englishes: A West African Perspective (pp. 113-129). Ibadan: Monsuro.

Akmajian, A., Demers, R. A., Farmer, A. K., \& Harnish, R. M. (2008). Linguistics: An Introduction to Language and Communication (5th ed.). New Delhi: Prentice-Hall.

Algeo, J. (2010). The Origins and Development of the English Language (6th ed.). Boston, MA: Wadsworth.

Amuseghan, S. A. (2007). ESL Curriculum in Secondary Schools in Nigeria: Issues and Challenges towards Communicative Competence. Nebula, 4, 319-333.

Awonusi, V. O. (1986). Regional Accents and Internal Variability in Nigerian English: A Historical Analysis. English Studies, 6, 555-560. http://dx.doi.org/10.1080/00138388608598483

Awonusi, V. O. (1987). The Identification of Standards within Institutionalized Non-Native Englishes: The Nigerian Experience. Lagos Review of English Studies, 9, 47-63.

Awonusi, S. (2004). Some Characteristics of Nigerian English Phonology. In A. B. K. Dadzie, \& S. Awonusi (Eds.), Nigerian English: Influences and Characteristics (pp. 203-225). Lagos: Concept Publications. 
Bamgbose, A. (1971). The English Language in Nigeria. In J. Spencer (Ed.), The English Language in West Africa (pp. 35-48). London: Longman.

Bamgbose, A. (1995). English in the Nigerian Environment. In A. Bamgbose, A. Banjo, \& A. Thomas (Eds.), New Englishes: A West African Perspective (pp. 9-26). Ibadan: Monsuro.

Bamiro, E. O. (1994). Lexico-Semantic Variation in Nigerian English. World Englishes, 13, 47-60. http://dx.doi.org/10.1111/j.1467-971X.1994.tb00282.x

Bamiro, E. O. (2006). Nativization Strategies: Nigerianisms at the Intersection of Ideology and Gender in Achebe's Fiction. World Englishes, 25, 315-328. http://dx.doi.org/10.1111/j.1467-971X.2006.00473.x

Bamiro, E. O. (2009). Contemporary English Usage: Recent Loanshifts in Nigerian English. Akungba Journal of English Studies and Communication, 1, 3-16.

Banjo, A. (1975). The University and the Standardization of the English Language in Nigeria. Plurilinguisme a l'Universite. Cabiers de l'Institute des langues Vivantes 26. Universite Catholique de Louvain, Louvain-la-Neuve, 133-147.

Banjo, A. (1995). On Codifying Nigerian English: Research So Far. In A. Bamgbose, A. Banjo, \& A. Thomas (Eds.), New Englishes: A West African Perspective (pp. 203-231). Ibadan: Monsuro.

Dadzie, A. B. K. (2004). The Concept of Nigerian English. In A. B. K. Dadzie, \& S. Awonusi (Eds.), Nigerian English: Influences and Characteristics (pp. 85-99). Lagos: Concept Publications.

Fafunwa, A. B. (1969). The Importance of the Mother Tongue as a Medium of Instruction. Nigeria Magazine, 102, 48-59.

Fafunwa, A. B., Macauley, J. I., \& Sokoya, J. A. F. (1989). Education in Mother Tongue: The Ife Primary Education Research Project (1970-1978). Ibadan: University Press.

Federal Ministry of Education (1981). National Policy on Education (Revised). Lagos: Federal Government Press. (First Published, 1977).

Finegan, E. (2008). Language: Its Structures and Use (5th ed.). Boston, MA: Wadsworth.

Fromkin, V., Rodman, R., \& Hyams, N. (2011). An Introduction to Language (Int. ed.). Boston, MA: Wadsworth.

Igboanusi, H. (2001). A Dictionary of Nigerian English. Ibadan: Sambooks Publishers.

Jibril, M. (1979). Regional Variation in Nigerian Spoken English. In E. Ubahakwe (Ed.), Varieties and Functions of English in Nigeria (pp. 43-53). Ibadan: African Universities Press.

Jowitt, D. (1991). Nigerian English Usage: An Introduction. Lagos: Longman.

Kujore, O. (1985). English Usage: Some Notable Nigerian Variations. Ibadan: Evans.

Kujore, O. (1995). Whose English? In A. Bamgbose, A. Banjo, \& A. Thomas (Eds.), New Englishes: A West African Perspective (pp. 367-388). Ibadan: Monsuro.

Mohammed, A. (1995). Communicative Competence Acquisition in Infelicitous Learning Environments: The Problem with SSS English in Nigeria. In A. Bamgbose, A. Banjo, \& A. Thomas (Eds.), New Englishes: A West African Perspective (pp. 130-152). Ibadan: Monsuro.

Okoro, O. (2004). Codifying Nigerian English: Some Practical Problems of Labelling. In S. Awonusi, \& E. A. Babalola (Eds.), The Domestication of English in Nigeria: A Festschrift in Honour of Abiodun Adetugbo (pp. 166-181). Lagos: University of Lagos Press.

Okunrinmeta, U. (2006). Beyond Grammatical Competence: The Use of English in the Izon Socio-Cultural Environment. UNAD Studies in Language and Literature, 2, 90-111.

Okunrinmeta, U. (2008a). A Linguistic Approach to the Meaning and Functions of the Town Crier in Nigeria's Multilingual Setting. In B. L. Virtanen, \& S. Owonibi (Eds.), The Mines of His Mind: Critical Reflections on the Works of Tayo Olafioye (pp. 37-53). Trenton, NJ: Africa World Press.

Okunrinmeta, U. (2008b). Twisting the English Language to Reflect the Nigerian Situation: A Portrayal of Tayo Olafioye's Creative Ingenuity. In B. L. Virtanen, \& S. Owonibi (Eds.), The Mines of His Mind: Critical Reflections on the Works of Tayo Olafioye (pp. 103-122). Trenton, NJ: Africa World Press.

Okunrinmeta, U. (2008c). Utilizing Perceived Pronunciation Deficiency for Positive Second Language Teaching and Learning: The Izon Experience. Lagos Review of English Studies, 16, 256-268.

Okunrinmeta, U. (2009a). Teaching English Stress in Nigeria's ESL Situation. Akungba Journal of English Studies and Communication, 1, 67-85.

Okunrinmeta, U. (2009b). Some Notable Lexico-Semantic Variations in Izon (Nigerian) Speakers of English. Geolinguistics, $35,55-74$.

Okunrinmeta, U. (2010). The Influence of Izon on the Syntax and Lexis of the English of Izon-English Bilinguals. Ph.D. Thesis, Lagos: University of Lagos. 
Okunrinmeta, U. (2011). Izon Syntax and the English of Izon-English Bilinguals. World Englishes, 30, 211-228. http://dx.doi.org/10.1111/j.1467-971X.2011.01699.x

Okunrinmeta, U. (2012). Bilingualism and Creativity in Language Use: The Nigerian Experience. Lagos Review of English Studies, 17, 216-232.

Okunrinmeta, U. (2013a). Izon Influences in Nigerian English Syntax. English Language and Literature Studies, 3, 30-43. http://dx.doi.org/10.5539/ells.v3n2p30

Okunrinmeta, U. (2013b). Singular-Plural Distinction in Izon and Its Influence on the Teaching/Learning of Plural Formation in English. Journal of Education and Learning, 2, 126-138. http://dx.doi.org/10.5539/jel.v2n2p126

Okunrinmeta, U. (2013c). Bilingualism and Linguistic Influence in Nigeria: Examples from the Works of Achebe and Emecheta. International Journal of English Linguistics, 3, 117-127. http://dx.doi.org/10.5539/ijel.v3n4p117

Orji, N. (1987). English Language Studies in Higher Education: Problems and Suggestions for Improvement. Lagos Review of English Studies, 9, 16-28.

Quirk, R., Greebaum, S., Leech, G., \& Svartvik, J. (2003). A Comprehensive Grammar of the English Language. London: Longman.

Udofot, I. (2004). Varieties of Spoken Nigerian English. In S. Awonusi, \& E. A. Babalola (Eds.), The Domestication of English in Nigeria: A Festschrift in Honour of Abiodun Adetugbo (pp. 93-113). Lagos: University of Lagos Press.

Uzoezie, R. U. (2004). The Linguistic Capital Market and Attitudinal Ambivalence of Nigerians to English as an Adopted Language. In S. Awonusi, \& E. A. Babalola (Eds.), The Domestication of English in Nigeria: A Festschrift in Honour of Abiodun Adetugbo (pp. 363-382). Lagos: University of Lagos Press. 